\title{
Clearing the Air: A Review of the Effects of Particulate Matter Air Pollution on Human Health
}

\author{
Jonathan O. Anderson • Josef G. Thundiyil • \\ Andrew Stolbach
}

Published online: 23 December 2011

(C) American College of Medical Toxicology 2011

\begin{abstract}
The World Health Organization estimates that particulate matter (PM) air pollution contributes to approximately 800,000 premature deaths each year, ranking it the 13th leading cause of mortality worldwide. However, many studies show that the relationship is deeper and far more complicated than originally thought. PM is a portion of air pollution that is made up of extremely small particles and liquid droplets containing acids, organic chemicals, metals, and soil or dust particles. PM is categorized by size and continues to be the fraction of air pollution that is most reliably associated with human disease. PM is thought to contribute to cardiovascular and cerebrovascular disease by the mechanisms of systemic inflammation, direct and indirect coagulation activation, and direct translocation into systemic circulation. The data demonstrating PM's effect on the cardiovascular system are strong. Populations subjected to long-term exposure to PM have a significantly higher cardiovascular incident and mortality rate. Short-term acute exposures subtly increase the rate of cardiovascular events within days of a pollution spike. The data are not as strong for PM's effects on cerebrovascular disease, though some data and similar mechanisms suggest a lesser result with smaller amplitude. Respiratory diseases are also exacerbated by exposure to PM. PM causes respiratory morbidity and mortality by creating oxidative stress and inflammation that leads to pulmonary anatomic and physiologic remodeling. The literature shows PM
\end{abstract}

J. O. Anderson $(\bowtie) \cdot$ J. G. Thundiyil

Department of Medical Education,

Orlando Health Emergency Medicine,

86 W. Underwood. Suite 200,

Orlando, FL 32806, USA

e-mail: janders120@gmail.com

\section{A. Stolbach}

Johns Hopkins University Emergency Medicine,

1830 E. Monument St. Suite 6-100,

Baltimore, MD 21287, USA causes worsening respiratory symptoms, more frequent medication use, decreased lung function, recurrent health care utilization, and increased mortality. PM exposure has been shown to have a small but significant adverse effect on cardiovascular, respiratory, and to a lesser extent, cerebrovascular disease. These consistent results are shown by multiple studies with varying populations, protocols, and regions. The data demonstrate a dose-dependent relationship between PM and human disease, and that removal from a PM-rich environment decreases the prevalence of these diseases. While further study is needed to elucidate the effects of composition, chemistry, and the PM effect on susceptible populations, the preponderance of data shows that PM exposure causes a small but significant increase in human morbidity and mortality. Most sources agree on certain "common sense" recommendations, although there are lonely limited data to support them. Indoor PM exposure can be reduced by the usage of air conditioning and particulate filters, decreasing indoor combustion for heating and cooking, and smoking cessation. Susceptible populations, such as the elderly or asthmatics, may benefit from limiting their outdoor activity during peak traffic periods or poor air quality days. These simple changes may benefit individual patients in both short-term symptomatic control and long-term cardiovascular and respiratory complications.

Keywords Particulate matter - Air pollution . Cardiovascular $\cdot$ Respiratory $\cdot$ Public policy

\section{Introduction}

While some correlation between poor air quality and human disease has been recognized since antiquity, the health effects of air pollution entered the world's consciousness in the twentieth century. In 1930, sulfur dioxide from local 
factory emissions mixed with a dense fog over the Meuse Valley in Belgium. Over 3 days, several thousand people were stricken with acute pulmonary symptoms, and 60 people died of respiratory causes [1]. In December 1952, a dense smog containing sulfur dioxide and smoke particulate descended upon London, resulting in more than 3,000 excess deaths over 3 weeks and as many as 12,000 through February 1953 [2]. The lethality of air pollution was immediately recognized but not well understood. To this day, because the effects of air pollution on illness occur at a population level, many clinicians fail to appreciate the relationship between air pollution and health.

The 1970 Clean Air Act (CAA) was the first major American regulatory effort aimed at both studying and setting limits on emissions and air pollution. The 1970 CAA defined the National Ambient Air Quality Standards (NAAQS [3]). These standards set limits on six primary pollutants found in air: carbon monoxide, lead, nitrogen dioxide, ozone, sulfur dioxide, and particulate matter (PM) [4].

PM is a complex mixture of extremely small particles and liquid droplets made up of acids, organic chemicals, metals, and soil or dust particles [5]. Sources of PM are both natural and anthropogenic. Manmade sources of PM include combustion in mechanical and industrial processes, vehicle emissions, and tobacco smoke. Natural sources include volcanoes, fires, dust storms, and aerosolized sea salt.

PM can be described by its "aerodynamic equivalent diameter" (AED). Particles of the same AED will tend to have the same settling velocity. Researchers traditionally subdivide particles into AED fractions based on how the particles are generated and where they deposit in human airways: $<10,<2.5$, and $<0.1 \mu \mathrm{m}\left(\mathrm{PM}_{10}, \mathrm{PM}_{2.5}\right.$, and $\mathrm{PM}_{0.1}$, respectively). Particles with a diameter greater than $10 \mu \mathrm{m}$ have a relatively small suspension half-life and are largely filtered out by the nose and upper airway. Researchers define a diameter between 2.5 and $10 \mu \mathrm{m}\left(\mathrm{PM}_{2.5-10}\right)$ as "coarse," less than $2.5 \mu \mathrm{m}$ as "fine," and less than $0.1 \mu \mathrm{m}$ as "ultrafine" particles. When interpreting PM research, it is important to appreciate that $\mathrm{PM}_{10}$ contains ultrafine $\left(\mathrm{PM}_{0.1}\right)$, fine $\left(\mathrm{PM}_{0.1-2.5}\right)$, and coarse $\left(\mathrm{PM}_{2.5-10}\right)$ fractions. In a mixed environmental sample, the total number and total surface area of these particles increases exponentially as the diameter of the particle decreases. However, the total particulate mass of a substance generally decreases exponentially with decreasing particle diameter. For example, in a sample of $\mathrm{PM}_{10}$, the numerical majority of particles would be ultrafine, but these particles would make up a negligible portion of the sample's total particulate mass (Fig. 1).

Studies show an increase in morbidity and mortality related to PM exposure. While the increased daily risks from PM exposure are modest for any individual, the costs of the worldwide healthcare burden are staggering when applied to populations. The World Health Organization estimates that
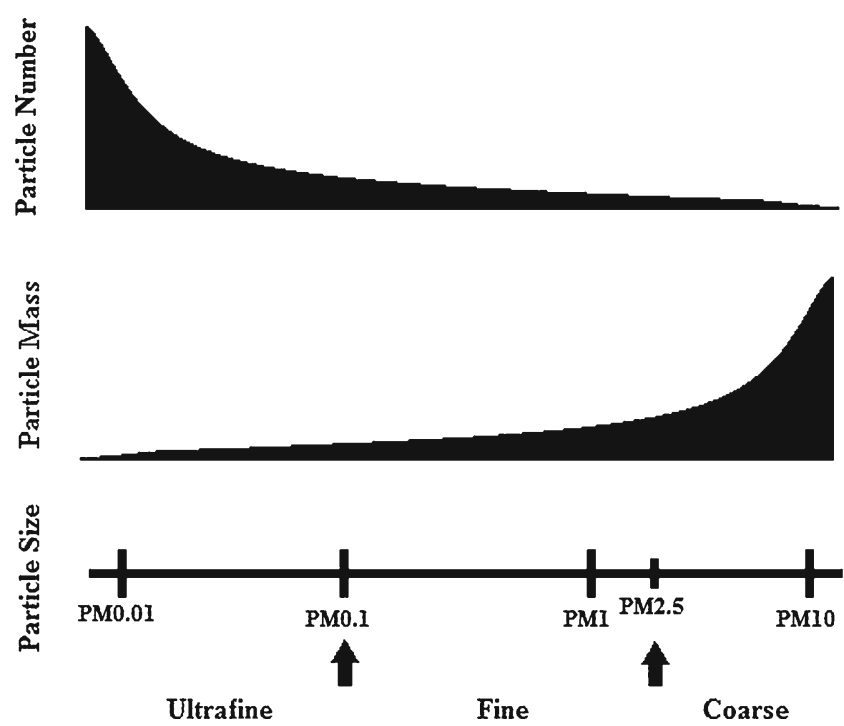

Fig. 1 A hypothetical mixed particle distribution

$\mathrm{PM}_{2.5}$ concentration contributes to approximately 800,000 premature deaths per year, ranking it the 13th leading cause of mortality worldwide [6].

This paper provides a review of the effect of ambient airborne PM on human morbidity and mortality. We review the current understanding of the mechanisms that underlie the observed clinical findings. Emphasis is placed primarily on research concerning the cardiovascular, respiratory, and cerebrovascular systems. This review concludes with public health recommendations based on a summary of the reported literature's findings.

\section{Methods}

The authors conducted a scientific review of all available literature published over the last 30 years. Our primary objective was to determine the association or lack of association between PM and human health. Our secondary objective was to summarize the proposed mechanisms for any purported associations based on existing human, animal, and in vitro studies. We initiated a PubMed database search using the MESH terms "PM," "particulate matter," "air pollution," "ultrafine particles," "fine particles," "coarse particles," "PM10," "PM2.5," and "PM0.1." Articles were selected and agreed upon by the authors based on relevance and impact. Effort was made to provide both positive and negative studies where appropriate. Emphasis was placed on well-conducted trials and epidemiological investigations. Studies were only excluded for redundancy. After analysis of the available data, this paper concludes with individual and public health recommendations based on the existing scientific evidence. 


\section{PM and Cardiovascular Health Effects}

Several large studies suggest that PM exerts significant effects on the cardiovascular system [7-9]. Research on this topic has focused on both the long-term effects of chronic PM exposure and the acute effects of increases in ambient PM on cardiovascular mortality. In a previous analysis [10], it was shown that for any increase in mortality caused by PM, two thirds of the effect was accounted for by the cardiovascular diseases.

\section{Cardiovascular Mechanisms}

Animal studies demonstrate a link between chronic PM exposure and the development of atherosclerosis via systemic inflammation $[11,12]$. Human studies show that the effects appear to be mediated by the inflammatory cytokines IL-6, TNF-á, and Creactive protein (CRP). Increases in both IL-6 [13] and CRP [14] have been associated with the development of acute myocardial infarction. Ruckerl et al. [15] described transient IL-6 and TNF$\alpha$ elevations in diabetic patients for 2 days following PM10 exposure. In a prospective cohort study of German patients, Hoffman et al. [16] associated exposure to PM2.5 with elevations in CRP. Other researchers demonstrated similar increases in CRP from PM10 exposure from both combustion [17] and organic matter [18]. In contrast, some studies have found only a weak or absent link between PM and markers of inflammation [19-22]. Discrepancies among studies appear related to differences in composition of PM, variable exposure to antiinflammatory medications, and differences in obtaining PM exposure data [10].

Acute exposure to PM causes changes in coagulation and platelet activation providing a more proximal link between PM and coronary artery disease. Many experts consider fibrinogen to be an important risk factor for cardiovascular disease [10]. Ruckerl et al. [15] associated a 5-day cumulative exposure to $\mathrm{PM}_{10}$ with increased fibrinogen levels in survivors of myocardial infarction. Other pro-coagulant factors, such as plasminogen activator fibrinogen inhibitor-1 (PAI-1), were also associated with PM elevations [17]. Intratracheal instillation of diesel exhaust particles led to increased platelet activation in hamsters and rapid thrombosis formation [23]. Further hamster studies also suggested that small particles translocate into the blood stream and exert prothrombotic effects [24]. Schicker et al. [18] showed that transient increases in PM10 exposure caused during hay-stacking increased platelet aggregation within $2 \mathrm{~h}$ of the activity. This activity also increased Von Willebrand factor and Factor VIII, markers of vascular endothelial activation.

\section{Long-Term Effects}

The "Harvard Six Cities study [7]," a cohort study published in 1993, followed 8,111 patients for 16-18 years and showed a $29 \%(95 \% \mathrm{CI}, 8-47 \%)$ increase in the adjusted mortality rate for the most polluted of the cities compared to the least polluted. Particulate air pollution was positively associated with death from lung cancer and cardiopulmonary disease (Table 1 ).

Pope et al. [8] followed this in 1995 with another prospective cohort study of 552,000 patients in 151 metropolitan areas using the American Cancer Society's Cancer Prevention 2 database (ACS CPS 2). These data showed a 17\% (95\% CI, 9-26\%) increase in all-cause mortality and a 31\% (95\% CI, 17$46 \%$ ) increase in cardiopulmonary mortality when comparing the most and least polluted cities. In 2002 [25] and 2004 [26], Pope et al. re-reviewed the expanding ACS CPS 2 database, now with 1.2 million participants, and extended the follow up. Their research demonstrated an average increase in cardiopulmonary mortality of $9 \%\left(95 \%\right.$ CI, 3-16\%) for each $10-\mu \mathrm{g} / \mathrm{m}^{3}$ increase in $\mathrm{PM}_{2.5}$. Subsequently, they determined that a $10-\mu \mathrm{g} /$ $\mathrm{m}^{3}$ increase in PM increased ischemic cardiovascular disease mortality by $18 \%(95 \% \mathrm{CI}, 14-23 \%)$ and mortality from arrhythmia, congestive heart failure, and cardiac arrest by $13 \%$ (95\% CI, 5-21\%).

In 2007, the Women's Health Initiative Study [27] followed a cohort of over 65,000 postmenopausal women with no previous
Table 1 Long-term effects of $\mathrm{PM}$ on the cardiovascular system

$P M$ particulate matter, $\triangle P M$ increase in ambient PM, $B S$ black smoke

\begin{tabular}{llllll}
\hline Author & Year & $\mathrm{PM}$ & $\Delta \mathrm{PM}\left(\mathrm{in} \mu \mathrm{g} / \mathrm{m}^{3}\right)$ & Outcome measure & Effect (95\% CI) \\
\hline Dockery et al. [17] & 1993 & $\mathrm{PM}_{10}$ & 18.6 & All-cause mortality & $26 \%(8-47)$ \\
Pope et al. [18] & 1995 & $\mathrm{PM}_{10}$ & 24.5 & All-cause mortality & $17 \%(9-26)$ \\
& & $\mathrm{PM}_{10}$ & 24.5 & Cardiopulmonary mortality & $31 \%(17-46)$ \\
Hoek et al. [28] & 2002 & $\mathrm{BS}$ & 10.3 & Cardiopulmonary mortality & $71 \%(10-167)$ \\
Pope et al. [25] & 2002 & $\mathrm{PM}_{2.5}$ & 10 & Cardiopulmonary mortality & $9 \%(3-16)$ \\
Pope et al. [26] & 2004 & $\mathrm{PM}_{2.5}$ & 10 & Ischemic CVD mortality & $18 \%(14-23)$ \\
& & $\mathrm{PM}_{2.5}$ & 10 & CHF, arrhythmia, CP arrest & $13 \%(5-21)$ \\
Miller et al. [27] & 2007 & $\mathrm{PM}_{2.5}$ & 10 & Cardiovascular event & $24 \%(9-41)$ \\
& & $\mathrm{PM}_{2.5}$ & 10 & Cardiovascular mortality & $76 \%(25-147)$ \\
Toren et al. [29] & 2007 & $\mathrm{PM}^{2}$ & Not measured & Cardiovascular mortality & $12 \%(7-19)$ \\
\hline
\end{tabular}


heart disease over approximately 6 years. The investigators revealed that long-term PM exposure in this population resulted in a $24 \%(95 \%$ CI, 9-41\%) increase in cardiovascular events and an astonishing $76 \%(95 \%$ CI, 25-147\%) increase in cardiovascular mortality per $10-\mu \mathrm{g} / \mathrm{m}^{3}$ increase in $\mathrm{PM}_{2.5}$. While these results had fairly wide confidence intervals, these data suggest that this cohort of patients may be particularly susceptible to ambient PM exposure.

The findings of cardiovascular effects from PM exposure are not unique to the USA. In the Netherlands, long-term exposure to traffic-related air pollution increased cardiopulmonary mortality by $71 \%$ (95\% CI, 10-167\%) [28]. A 2007 cohort study [29] of 250,000 Swedish construction workers from 1972 to 2002 found that workers with occupational PM exposure had a $12 \%(95 \% \mathrm{CI}, 7-19 \%)$ increase in ischemic cardiovascular disease mortality.

While increases in PM have been consistently shown to increase cardiovascular morbidity and mortality, the effects of PM reduction have also been studied. In the 72 months following the ban of bituminous coal sales in Ireland in 1990, black smoke concentration decreased by $35.6 \mu \mathrm{g} / \mathrm{m}^{3}$ over this time, and standardized respiratory and cardiovascular mortality decreased by $15.5 \%$ (95\% CI, $12-19 \%)$ and $10.3 \%$ (95\% CI, 8-13\%), respectively [30]. An 8-year extension of the Harvard Six Cities data studied the population subset that moved from areas of higher to lower PM concentration [31], finding that a $10-\mu \mathrm{g} / \mathrm{m}^{3}$ decrease in $\mathrm{PM}_{2.5}$ resulted in a $27 \%$ (95\% CI, 5-43\%) decrease in overall mortality.

\section{Short-Term Effects}

A 2001 review [32] of 12 prior studies concluded that a 10- $\mu \mathrm{g} /$ $\mathrm{m}^{3}$ increase in $\mathrm{PM}_{10}$ increased hospital admissions for congestive heart failure and ischemic heart disease by $0.8 \%(95 \% \mathrm{CI}$,
$0.5-1.2 \%)$ and $0.7 \%(95 \%$ CI, $0.4-1.0 \%)$, respectively. Similarly, a 2006 review [33] showed a $0.44 \%$ (95\% CI, $0.02-$ $0.86 \%$ ) and $1.28 \%$ (95\% CI, $0.78-1.78 \%$ ) increase in admissions for ischemic heart disease and heart failure for a $10-\mu \mathrm{g} / \mathrm{m}^{3}$ increase in $\mathrm{PM}_{2.5}$, respectively. In a smaller trial, Pope et al. [34] used a case-crossover of 12,000 patients in Utah to show that a $10-\mu \mathrm{g} / \mathrm{m}^{3}$ increase in $\mathrm{PM}_{2.5}$ led to a $4.5 \%(95 \%$ CI, $1.1-$ $8.0 \%$ ) increase in acute ischemic coronary events. In an analysis of PM concentrations from 20 major cities in the USA using the National Morbidity Mortality Air Pollution Study (NMMAPS) data, Samet et al. [9] showed a $10-\mu \mathrm{g} / \mathrm{m}^{3}$ increase in $\mathrm{PM}_{10}$ caused an increase in all-cause and cardiopulmonary mortality by $0.5 \%(95 \% \mathrm{CI}, 0.1-0.9 \%)$ and $0.7 \%(95 \% \mathrm{CI}, 0.2-$ $1.2 \%$ ), respectively (Table 2 ).

Similar results have been found in Japan [35], Australia, and New Zealand [36]. In 2008, Samoli et al. [37] re-analyzed the data of the APHEA 2, NMMAPS, and several Canadian studies in order to assess the coherence of findings using the same methods for all three sets of data. They were able to show an increase in daily all-cause mortality for Canadian, European, and US cities. Interestingly, the short-term mortality resulting from acute increases in PM are not limited to the critically ill or dying. In fact, much of the mortality occurred among active individuals with one or more risk factors.

\section{PM and Respiratory Health Effects}

While much of the interest in PM has focused on the cardiovascular system $[7,8]$, many studies evaluated the association between PM exposure and respiratory illness. Researchers have evaluated endpoints including respiratory symptoms, medication use, lung function, health-care utilization, and mortality.
Table 2 Short-term effects of $\mathrm{PM}$ on the cardiovascular system

$P M$ particulate matter, $\triangle P M$ increase in ambient PM, TSP total suspended particles, IHD ischemic heart disease, $C H F$ congestive heart failure, $A M I$ acute myocardial infarction

\begin{tabular}{|c|c|c|c|c|c|}
\hline Author & Year & $\mathrm{PM}$ & $\begin{array}{l}\Delta \mathrm{PM} \\
\left(\text { in } \mu \mathrm{g} / \mathrm{m}^{3}\right)\end{array}$ & Outcome measure & Effect \\
\hline \multirow[t]{2}{*}{ Morris [32] } & \multirow[t]{2}{*}{2001} & $\mathrm{PM}_{10}$ & 10 & Hospital admission, IHD & $0.7 \%(95 \%$ CI, $0.4-1.0)$ \\
\hline & & $\mathrm{PM}_{10}$ & 10 & Hospital admission, $\mathrm{CHF}$ & $0.8 \%(95 \%$ CI, $0.5-1.2)$ \\
\hline \multirow{2}{*}{$\begin{array}{l}\text { Domicini et } \\
\text { al. } \\
{[33]}\end{array}$} & \multirow[t]{2}{*}{2006} & $\mathrm{PM}_{2.5}$ & 10 & Hospital admission, IHD & $0.44 \%(95 \%$ CI, $0.02-0.86)$ \\
\hline & & $\mathrm{PM}_{2.5}$ & 10 & Hospital admission, CHF & $1.28 \%(95 \% \mathrm{CI}, 0.78-1.78)$ \\
\hline \multirow{3}{*}{$\begin{array}{l}\text { Barnett et al. } \\
{[36]}\end{array}$} & \multirow[t]{3}{*}{2006} & $\mathrm{PM}_{2.5}$ & 10 & Hospital admission, IHD & $1.6 \%(95 \%$ CI, $0.7-2.4)$ \\
\hline & & $\mathrm{PM}_{2.5}$ & 10 & Hospital admission, $\mathrm{CHF}$ & $3.6 \%(95 \%$ CI, $1.8-5.4)$ \\
\hline & & $\mathrm{PM}_{2.5}$ & 10 & Hospital admission, AMI & $2.7 \%(95 \%$ CI, $1.3-4.2)$ \\
\hline $\begin{array}{l}\text { Pope et al. } \\
\text { [34] }\end{array}$ & 2006 & $\mathrm{PM}_{2.5}$ & 10 & Ischemic cardiac event & $4.5 \%(95 \%$ CI, $1.1-8.0)$ \\
\hline \multirow{2}{*}{$\begin{array}{l}\text { Samet et al. } \\
\text { [9] }\end{array}$} & \multirow[t]{2}{*}{2000} & $\mathrm{PM}_{10}$ & 10 & All-cause mortality & $0.5 \%(95 \%$ CI, $0.1-0.9)$ \\
\hline & & $\mathrm{PM}_{10}$ & 10 & $\begin{array}{l}\text { Cardiopulmonary } \\
\text { mortality }\end{array}$ & $0.7 \%(95 \% \mathrm{CI}, 0.2-1.2)$ \\
\hline \multirow{2}{*}{$\begin{array}{l}\text { Omori et al. } \\
{[35]}\end{array}$} & \multirow[t]{2}{*}{2003} & TSP & 20 & All-cause mortality & $1.0 \%(95 \%$ CI, $0.8-1.3)$ \\
\hline & & TSP & 20 & $\begin{array}{l}\text { Cardiopulmonary } \\
\text { mortality }\end{array}$ & $1.1 \%(95 \%$ CI, $0.7-1.5)$ \\
\hline
\end{tabular}




\section{Respiratory Mechanisms}

PM triggers pulmonary oxidative stress and inflammation. Human airway epithelial cells exposed to PM express inflammatory cytokines $[38,39]$. Alveolar macrophages exhibit respiratory burst activity, producing reactive oxygen species, nitrogen species, and release TNF- $\alpha$ and IL-1 after exposure [40]. In addition to oxidative stress generated from activation of inflammatory cells, reactive oxygen species may be directly generated from the surface of particles [41]. These responses can be potent and were shown to cause measurable pulmonary damage after only a single exposure in mice [42]. This oxidative damage is associated with the primary development of asthma and chronic obstructive pulmonary disease (COPD). Long-term exposure to PM results in airway remodeling and chronic inflammation [43]. PM may also contribute to asthma development by enhancing atopy and IgE responses [44, 45]. Several controlled human experiments have demonstrated adverse affects on the pulmonary system. PM exposure has been shown to increase airway responsiveness to methacholine [46], increase neutrophil numbers in bronchial lavage [47], decrease $\mathrm{CO}$ diffusion capacity, and decrease maximum mid-expiratory flow [48].

\section{Respiratory Symptoms and Medication Usage}

As part of the Children's Health Study, McConnell et al. [49] found that asthmatic children had a $40 \%(95 \%$ CI, $10-80 \%)$ increased risk of bronchitic symptoms for a $19-\mu \mathrm{g} / \mathrm{m}^{3}$ increase in $\mathrm{PM}_{10}$. Similarly, a $10-\mu \mathrm{g} / \mathrm{m}^{3}$ increase in $\mathrm{PM}_{10}$ led to a $12 \%$ (95\% CI, 4-22\%) increase in severe asthma symptoms in Seattle children [50]. A study of inner-city asthmatic children revealed an association between $\mathrm{PM}_{2.5}$ increases and missed school days for asthma [51]. A study of adult Parisians [52] showed a $41 \%$ (95\% CI, 16-71\%) increase in acute asthma exacerbations per $10-\mu \mathrm{g} / \mathrm{m}^{3}$ increase in $\mathrm{PM}_{10}$. Interestingly, nearly all PM levels in these studies were below levels set out in the NAAQS.

Respiratory medication use also increased in times of peak PM concentration. Use of rescue bronchodilators increased as ambient $\mathrm{PM}_{2.5}$ rose in Denver [53] and the Northeast USA [54]. A review of 80,000 Alaskan Medicaid enrollees found prescription rates for bronchodilators increased by $18.1 \%$ and $28.8 \%$ when $\mathrm{PM}_{10}$ exceeded 34 and $61 \mu \mathrm{g} / \mathrm{m}^{3}$, respectively [55]. Together, these data suggest that increases in ambient PM worsen asthma symptoms.

\section{PM and Pulmonary Function}

Several recent studies suggest that PM levels may affect lung function and lung development. The Children's Health Study [56] followed 1,759 patients over 8 years, finding that children who lived in communities with the highest PM concentrations were five times more likely to have low FEV1 than those in communities with the lowest PM concentrations. Moreover, children that moved from areas of higher to lower $\mathrm{PM}_{10}$ concentration had increased growth in lung function, and those that moved from areas of lower to higher $\mathrm{PM}_{10}$ concentration had decreased growth in lung function [57]. Even children with better lung function were susceptible to new onset asthma when exposed to higher levels of $\mathrm{PM}_{2.5}$ [58]. Lower lung function has also been shown for children with cystic fibrosis exposed to higher levels of $\mathrm{PM}_{10}$ and $\mathrm{PM}_{2.5}$ [59].

Similar inverse correlations between PM exposure and individual PEFR and FEV1 measurements have been reproduced internationally [60]. In the developing world, where indoor biomass burning can lead to PM levels exceeding $200 \mu \mathrm{g} / \mathrm{m}^{3}$, researchers demonstrated that chronic exposure in children can lead to adult COPD, increased rates of lung infection, and impaired lung function [61].

In adults, effects of PM on lung function have been found primarily in susceptible populations. Investigators showed that asthmatic Londoners taking walks in areas of high PM had significantly higher reduction in FEV1, FVC, and increases in sputum biomarkers of inflammation [62]. In elderly patients, $\mathrm{PM}_{10}$ and $\mathrm{PM}_{2.5}$ increases were associated with decreases in PEFR [63]. In COPD patients, decrements in lung function were associated with increases in $\mathrm{PM}_{2.5}$ concentration [64]. Downs et al. [65] demonstrated that declines in $\mathrm{PM}_{10}$ concentration may actually lead to an attenuated decline in lung function in adult patients. However, research on healthy adults has not as consistently shown an association between PM and respiratory compromise [66].

\section{PM and Respiratory-Related Healthcare Utilization}

In a large case-control study [67], $10 \mu \mathrm{g} / \mathrm{m}^{3}$ increases in $\mathrm{PM}_{2.5}$ were associated with a $9 \%(95 \% \mathrm{CI}, 4-14 \%)$ increase in bronchiolitis hospitalizations for infants. Large pediatric studies demonstrate increased asthma ED visits for increases in PM [68] and that $\mathrm{PM}_{10}$ increases of $6.5 \mu \mathrm{g} / \mathrm{m}^{3}$ are associated with a $15 \%(95 \% \mathrm{CI}, 2-30 \%)$ increase in respiratoryrelated hospital admissions [69] (Table 3).

For adults, several large studies have demonstrated an association between respiratory hospitalization and ambient $\mathrm{PM}_{10}$ [70] and $\mathrm{PM}_{2.5}$ [71] concentrations. This includes admissions for asthma, COPD, and pneumonia. The effects appear to be stronger for elderly patients with even shortterm exposures [72]. A study [73] of 12 million Medicare enrollees in 108 counties demonstrated significant increases in respiratory hospitalizations for increases in $\mathrm{PM}_{2.5}$ in the Eastern USA. Because the same effects were not consistently observed in the Western USA, the authors suggested that morbidity may be related to the specific chemical constituents of PM which differs across the country. Several recent 
Table 3 The effects of PM on respiratory admissions
$P M$ particulate matter, $\triangle P M$ increase in ambient PM

\begin{tabular}{|c|c|c|c|c|c|}
\hline Author & Year & PM & $\begin{array}{l}\Delta \mathrm{PM} \\
\left(\text { in } \mu \mathrm{g} / \mathrm{m}^{3} \text { ) }\right.\end{array}$ & Outcome measure & Effect $(95 \% \mathrm{CI})$ \\
\hline Karr et al. [67] & 2006 & $\mathrm{PM}_{2.5}$ & 10 & $\begin{array}{l}\text { Infant bronchiolitis } \\
\text { admissions }\end{array}$ & $9 \%(4-14)$ \\
\hline Lin et al. [68] & 2005 & $\mathrm{PM}_{10-2.5}$ & 6.5 & $\begin{array}{l}\text { Pediatric respiratory } \\
\text { admissions }\end{array}$ & $17 \%(6-29)$ \\
\hline Samoli et al. [92] & 2011 & $\mathrm{PM}_{10}$ & 10 & Pediatric asthma admissions & $2.54 \%(0.06-5.08)$ \\
\hline Peng et al. [93] & 2008 & $\mathrm{PM}_{10-2.5}$ & 10 & Respiratory admissions & $0.33 \%(-0.21-0.86)$ \\
\hline \multirow{2}{*}{$\begin{array}{l}\text { Zanobetti et al. } \\
{[70]}\end{array}$} & \multirow[t]{2}{*}{2009} & $\mathrm{PM}_{2.5}$ & 10 & Respiratory admissions & $2.07 \%(1.2-2.95)$ \\
\hline & & $\mathrm{PM}_{2.5}$ & 17 & Pneumonia admissions & $6.5 \%(1.1-11.4)$ \\
\hline \multirow{2}{*}{$\begin{array}{l}\text { Medina-Ramon } \\
\text { et al. [71] }\end{array}$} & \multirow[t]{2}{*}{2006} & $\mathrm{PM}_{10}$ & 10 & COPD admissions & $1.47 \%(0.93-2.01)$ \\
\hline & & $\mathrm{PM}_{10}$ & 10 & Pneumonia admissions & $0.84 \%(0.5-1.19)$ \\
\hline $\begin{array}{l}\text { Dominici et al. } \\
\text { [33] }\end{array}$ & 2006 & $\mathrm{PM}_{2.5}$ & 10 & COPD admissions & $1.61 \%(0.56-2.66)$ \\
\hline $\begin{array}{l}\text { McGowan et al. } \\
\text { [77] }\end{array}$ & 2001 & $\mathrm{PM}_{10}$ & 14.8 & Respiratory admissions & $3.37 \%(2.34-4.40)$ \\
\hline Ostro et al. [94] & 2009 & $\mathrm{PM}_{2.5}$ & 14.6 & $\begin{array}{l}\text { Pediatric respiratory } \\
\text { admissions }\end{array}$ & $4.1 \%(1.8-6.4)$ \\
\hline
\end{tabular}

large studies have provided further evidence that the strength of PM effect may depend on the composition [74]. Investigations in European cities [75], Asian cities [76], and Oceania cities [77] have demonstrated a consistent and small though significant association between PM concentrations and emergency visits for respiratory diseases.

\section{PM and Respiratory Mortality}

The Six Cities study [7], 20 cities study [9], and ACS CPS 2 [8] cohort revealed an association between PM exposure and cardiopulmonary mortality. These studies did not, however, separate the impact on respiratory mortality versus cardiovascular mortality. A follow-up investigation using data from the 20 Cities Study revealed a $0.87 \%(95 \%$ CI, $0.38-1.36 \%)$ increased respiratory mortality for short-term increases in $\mathrm{PM}_{10}$ by $10 \mu \mathrm{g} / \mathrm{m}^{3}$ [78]. This was subsequently expanded into a larger cohort of 112 US cities, where researchers found a $1.68 \%$ (95\% CI, 1.04-2.33\%) increase in respiratory mortality for every $10-\mu \mathrm{g} / \mathrm{m}^{3}$ increase in $\mathrm{PM}_{2.5}$ [79]. A study of California counties similarly revealed an increased respiratory mortality with increases in $\mathrm{PM}_{10}$ [80].
These results have been reproduced in countries around the world. A Norwegian study [81] demonstrated a $17 \%$ $(95 \%$ CI, 9-25\%) increase in mortality risk from COPD for every quartile increase in $\mathrm{PM}_{2.5}$. In a study of 275,000 adults in ten Italian cities [82], short-term $\mathrm{PM}_{10}$ increases led to a $2.29 \%(95 \%$ CI, $1.03-3.58 \%)$ increase in respiratory mortality. Similar results for increased respiratory mortality have been found in Asian cities where researchers have demonstrated excess respiratory mortality risk for increases in $\mathrm{PM}_{10}$ [83]. Nearly identical effect sizes for respiratory mortality were found in the APHEA2 trial which studied this relationship across 29 European cities [84]. One study even demonstrated an association between $\mathrm{PM}_{10}$ and respiratory mortality in children under age five [85] (Table 4).

\section{PM and Cerebrovascular Health Effects}

Ischemic cerebrovascular and cardiovascular disease share many risk factors, features, and pathophysiological mechanisms. As an example, CRP, similar to cardiovascular disease, has also been implicated in the genesis of stroke [86].
Table 4 The effects of PM on respiratory mortality

$P M$ particulate matter, $\triangle P M$ increase in ambient PM

\begin{tabular}{llllll}
\hline Author & Year & $\mathrm{PM}$ & $\Delta \mathrm{PM}\left(\mathrm{in} \mu \mathrm{g} / \mathrm{m}^{3}\right)$ & Outcome measure & Effect $(95 \% \mathrm{CI})$ \\
\hline Zeka et al. [78] & 2005 & $\mathrm{PM}_{10}$ & 10 & Respiratory mortality & $0.87 \%(0.38-1.36)$ \\
Zanobetti et al. [79] & 2009 & $\mathrm{PM}_{2.5}$ & 10 & Respiratory mortality & $1.68 \%(1.04-2.33)$ \\
Wong et al. [83] & 2008 & $\mathrm{PM}_{10}$ & 10 & Respiratory mortality & $0.62 \%(0.22-1.02)$ \\
Analitis et al. [84] & 2006 & $\mathrm{PM}_{10}$ & 10 & Respiratory mortality & $0.58 \%(0.21-0.95)$ \\
Hales et al. [91] & 2010 & $\mathrm{PM}_{10}$ & 10 & Respiratory mortality & $1.3 \%(0.5-2.1)$ \\
Pope et al. [25] & 2002 & $\mathrm{PM}_{2.5}$ & 10 & Lung cancer mortality & $8 \%(1-16)$ \\
Ostro et al. [80] & 2006 & $\mathrm{PM}_{2.5}$ & 10 & Respiratory mortality & $2.2 \%(0.6-3.9)$ \\
\hline
\end{tabular}


However, the evidence linking PM and stroke is more sporadic and the mechanisms less well understood.

Dominici et al. [33] reviewed an air quality data for 204 US urban counties and showed that a $10-\mu \mathrm{g} / \mathrm{m}^{3}$ increase in ambient $\mathrm{PM}_{2.5}$ increased the risk of hospitalization for cerebrovascular events by $0.8 \%$ ( $95 \% \mathrm{CI}, 0.3-1.3 \%)$. A separate review [87] of Medicare patients found an increase of $1.03 \%$ (95\% CI, $0.04-2.04 \%$ ) for hospital admission for ischemic stroke for each $10-\mu \mathrm{g} / \mathrm{m}^{3}$ increase in $\mathrm{PM}_{10}$. Still other investigators found a previous day $\mathrm{PM}_{2.5}$ increase of $5.2 \mu \mathrm{g} / \mathrm{m}^{3}$ led to a $3 \%(95 \% \mathrm{CI}, 0-7 \%)$ increase in risk of TIA and ischemic stroke.

In contrast, a recent large prospective multi-center stroke registry found no increase in the general population for ischemic stroke from exposure to $\mathrm{PM}_{2.5}$. There was, however, an $11 \%(95 \% \mathrm{CI}, 1-22 \%)$ increase in stroke risk in exposed patients with diabetes [88]. A large case-crossover study found an association between other components of air pollution ( $\mathrm{NO} 2$ and $\mathrm{CO}$ ) and cerebrovascular disease, but no correlation was noted with changing PM levels [89]. Similarly, a large registry of first-ever strokes found no association with $\mathrm{PM}_{10}$ for ischemic or hemorrhagic stroke [90].

There are several reasons why studies of PM and cerebrovascular disease have produced conflicting results. Some studies do not completely adjust for all confounding variables. There is further heterogeneity due to differences in the definition of cerebrovascular disease, or whether pollution is measured on the day of admission or symptom onset [88]. Further, it is possible that exposure to PM may not contribute to an overall increase in cerebrovascular disease, but only trigger events in vulnerable populations.

\section{Recommendations and Conclusions}

In evaluating the literature, there appears to be a small, but consistent and significant, effect of PM on human health. Overall, the small individual effects result in a large global public health burden. Notably, the effects are most pronounced for cardiovascular disease. Several studies have demonstrated an increase in cardiovascular mortality and hospitalizations. There are similar effects, of smaller amplitude, in respiratory disease. More study is needed to clarify the relationship between PM and cerebrovascular disease.

There are limitations to much of the available PM research. Most studies do not use individual exposure data. Rather, air monitors in population centers are used as surrogates for individual exposure. Even after adjusting these data for time spent in traffic, exposure to second-hand smoke, etc., estimates may not be accurate. Despite these limitations, different types of studies conducted in different locations find similar results. A dose-response relationship between PM exposure and adverse effects has been identified, and improvement in health endpoints is observed when the PM exposures are reduced. Overall, the available evidence suggests a causal association between long- and short-term PM exposure and cardiovascular and respiratory morbidity and mortality.

Further research is still needed to fully understand how PM affects human health. While studies show increased PM concentration has adverse health affects, the actual composition of particulates that is harmful has not yet been elucidated. Further studies are also needed to clarify the time course of PMinduced effects. In limited studies, some effects seem to appear within hours, while other reach their zenith within several days peak PM exposure. The data on this "lag time" effect can
Table 5 Air quality index and recommendations

\section{EPA-456/F-09-002}

Air quality index: a guide to air quality and your health. EPA, August 2009

$A Q I$ air quality index

${ }^{a}$ People with heart or lung disease, children, or older adults

\begin{tabular}{|c|c|c|c|c|}
\hline AQI level & $\begin{array}{l}\mathrm{AQI} \\
\text { value }\end{array}$ & $\mathrm{PM}_{2.5}$ & $\mathrm{PM}_{10}$ & $\begin{array}{l}\text { Actions to protect your } \\
\text { health from particle pollution }\end{array}$ \\
\hline Good & $0-50$ & $0-15$ & $0-50$ & None \\
\hline Moderate & $51-100$ & $16-35$ & $51-154$ & $\begin{array}{l}\text { Unusually sensitive people } \\
\text { should consider reducing } \\
\text { prolonged or heavy exertion }\end{array}$ \\
\hline $\begin{array}{l}\text { Unhealthy for } \\
\text { sensitive groups }\end{array}$ & $101-150$ & $36-65$ & $155-254$ & $\begin{array}{l}\text { Susceptible groups }{ }^{\mathrm{a}} \text { should reduce } \\
\text { prolonged or heavy exertion } \\
\text { Everyone else should limit prolonged } \\
\text { or heavy exertion }\end{array}$ \\
\hline $\begin{array}{l}\text { Unhealthy for } \\
\text { sensitive groups }\end{array}$ & $151-200$ & $66-150$ & $255-354$ & $\begin{array}{l}\text { Susceptible groups }{ }^{\mathrm{a}} \text { should avoid } \\
\text { all physical activity outdoors } \\
\text { Everyone else should avoid prolonged } \\
\text { or heavy exertion }\end{array}$ \\
\hline Very unhealthy & $201-300$ & $>150$ & $>354$ & $\begin{array}{l}\text { Susceptible groups }{ }^{\mathrm{a}} \text { should remain } \\
\text { indoors and keep activity levels low } \\
\text { Everyone else should avoid all physical } \\
\text { activity outdoors }\end{array}$ \\
\hline
\end{tabular}


be contradictory, and this phenomenon remains incompletely understood. The true biological mechanisms leading to PMinduced pathology continue to be investigated. Also, while regional exposure data has become standard for PM epidemiology, studies with true individual exposure have yet to be fully realized. Finally, studies defining susceptible populations will help to shape further population-based recommendations.

\section{Clinical Recommendations}

When a patient presents with an acute illness, the clinician will not be able to determine the degree to which PM contributed. In illnesses where PM is known to contribute to risk, that percentage risk increase is usually measured in the single digits. Therefore, it is unlikely that there will ever be specific therapies for PM-related illness. Rather, health care providers should be familiar with prevention strategies for PM-related illness. Indoor PM exposure can be minimized by using air conditioning, particulate air filters, avoiding use of indoor combustion for cooking and heating, and smoking cessation [95]. Susceptible groups may benefit from limiting their outdoor exercise during peak traffic periods or poor air quality days [96]. The Air Quality Index (AQI) (http://airnow.gov) provides up-to-date information regarding local concentrations of PM and other pollutants. While government agencies have put out recommendations for minimizing PM exposure, peer-reviewed controlled data are limited for the implementation of these recommendations (Table 5).

Though PM exposure is ubiquitous, there is no defined and studied "safe" level. Patient education and behavioral modification strategies may contribute to better overall health. Additionally, these data can enable policy makers, after weighing the economic impact, to enforce or strengthen existing legislation that limits PM exposure. Volcanoes, forest fires, and other natural PM sources are part of our world and are unavoidable. However, by reducing modifiable PM exposure, we will likely see reductions in morbidity and mortality.

\section{References}

1. Nemery B, Hoek P, Nemmar A (2001) The Meuse Valley fog of 1930: an air pollution disaster. Lancet 357:704-708

2. Bell ML, Davis DD (2001) Reassessment of the lethal London fog of 1952: novel indicators of acute and chronic consequences of acute exposure to air pollution. Environ Health Perspect 109(3): 389-394

3. Anonymous. "History | Clean Air Act | US EPA". US Environmental Protection Agency, 16 Nov 2010. http://www.epa.gov/air/ caa/caa_history.html. Accessed on 22 July 2011
4. Anonymous. "National Ambient Air Quality Standards (NAAQS) Air and Radiation | US EPA". US Environmental Protection Agency, 19 July 2011. http://www.epa.gov/air/criteria.html. Accessed on 22 July 2011

5. Anonymous. "Particulate Matter $\mid$ Air \& Radiation | US EPA". US Environmental Protection Agency, 6 July 2011. http://www.epa. gov/pm/. Accessed on 22 July 2011

6. World Health Organization (2002) World health report 2002. World Health Organization, Geneva

7. Dockery D, Pope C, Xu X, Spengler J, Ware J et al (1993) An association between air pollution and mortality in six U.S. cities. NEJM 329(24):1753-1759

8. Pope C, Thun M, Namboodiri M, Dockery D, Evans J et al (1995) Particulate air pollution as a predictor of mortality in a prospective study of U.S. adults. Am J Respir Crit Care Med 151:669-674

9. Samet J, Dominici F, Curriero F, Coursac I, Zeger S (2000) Fine particulate air pollution and mortality in 20 U.S. cities, 1987-1994. NEJM 343(24):1742-1749

10. Brook R, Rajagopalan S, Pope A, Brook J, Bhatnagar A, Diez-Roux A et al (2010) Particulate matter air pollution and cardiovascular disease: an update to the scientific statement from the American Heart Association. Circulation 121:2331-2378

11. Chen L, Nadziejko C (2005) Effects of subchronic exposures to concentrated ambient particles (CAPs) in mice. V. CAPs exacerbate aortic plaque development in hyperlipidemic mice. Inhal Toxicol 17(4-5):217-224

12. Sun Q, Wang A, Jin X, Natanzon A, Duquaine D et al (2005) Long-term air pollution exposure and acceleration of atherosclerosis and vascular inflammation in an animal model. JAMA 294 (23):3003-3010

13. Ridker P, Rifai N, Stampfer M, Hennekens C (2000) Plasma concentration of interleukin- 6 and the risk of future myocardial infarction among apparently healthy men. Circulation 101(15): $1767-1772$

14. Wennberg P, Wensley F, Di Angelantonio E, Johansson L, Boman $\mathrm{K}$ et al (2011) Haemostatic and inflammatory markers are independently associated with myocardial infarction in men and women. Thromb Res (in press)

15. Rückerl R, Ibald-Mulli A, Koenig W, Schneider A, Woelke G et al (2006) Air pollution and markers of inflammation and coagulation in patients with coronary heart disease. Am J Respir Crit Care Med 173(4):432-441

16. Hoffmann B, Moebus S, Dragano N, Stang A, Möhlenkamp S et al (2009) Chronic residential exposure to particulate matter air pollution and systemic inflammatory markers. Environ Health Perspect 117(8):1302-1308

17. Chuang K, Chan C, Su T, Lee C, Tang C (2007) The effect of urban air pollution on inflammation, oxidative stress, coagulation, and autonomic dysfunction in young adults. Am J Respir Crit Care Med 176(2):370-376

18. Schicker B, Kuhn M, Fehr R, Asmis L, Karagiannidis C et al (2009) Particulate matter inhalation during hay storing activity induces systemic inflammation and platelet aggregation. Eur $\mathrm{J}$ Appl Physiol 105(5):771-778

19. Sullivan J, Hubbard R, Liu S, Shepherd K, Trenga C et al (2007) A community study of the effect of particulate matter on blood measures of inflammation and thrombosis in an elderly population. Environ Health 6:3

20. Steinvil A, Kordova-Biezuner L, Shapira I, Berliner S, Rogowski O (2008) Short-term exposure to air pollution and inflammationsensitive biomarkers. Environ Res 106(1):51-61

21. Forbes L, Patel M, Rudnicka A, Cook D, Bush T et al (2009) Chronic exposure to outdoor air pollution and markers of systemic inflammation. Epidemiology 20(2):245-253

22. Diez Roux A, Auchincloss A, Astor B, Barr R, Cushman M et al (2006) Recent exposure to particulate matter and C-reactive 
protein concentration in the multi-ethnic study of atherosclerosis. Am J Epidemiol 164(5):437-448

23. Nemmar A, Hoet P, Dinsdale D, Vermylen J, Hoylaerts M et al (2003) Diesel exhaust particles in lung acutely enhance experimental peripheral thrombosis. Circulation 107(8):1202-1208

24. Nemmar A, Hoylaerts M, Hoet P, Dinsdale D, Smith T et al (2002) Ultrafine particles affect experimental thrombosis in an in vivo hamster model. Am J Respir Crit Care Med 166:998-1004

25. Pope C, Burnett R, Thun M, Calle E, Krewski D et al (2002) Lung cancer, cardiopulmonary mortality, and long-term exposure to fine particulate air pollution. JAMA 287:1132-1141

26. Pope C, Burnett R, Thurston G, Thun M, Calle E et al (2004) Cardiovascular mortality and long-term exposure to particulate air pollution. Circulation 109:71-77

27. Miller K, Siscovick D, Sheppard L, Shepherd K, Sullivan J et al (2007) Long-term exposure to air pollution and incidence of cardiovascular events in women. NEJM 356:447-458

28. Hoek G, Brunekreef B, Goldbohm S, Fischer P, van den Brandt P (2002) Association between mortality and indicators of trafficrelated air pollution in the Netherlands: a cohort study. Lancet 360:1203-1209

29. Toren K, Bergdahl I, Nilsson T, Jarvholm B (2007) Occupational exposure to particulate air pollution and mortality due to ischaemic heart disease and cerebrovascular disease. Occup Eviron Med 64:515-519

30. Clancy L, Goodman P, Sinclair H, Dockery D (2002) Effect of airpollution control on death rates in Dublin, Ireland: an intervention study. Lancet 360:1210-1214

31. Laden F, Schwartz J, Speizer FE, Dockery DW (2006) Reduction in fine particulate air pollution and mortality: extended follow-up of the Harvard Six Cities study. Am J Respir Crit Care Med 173:667-672

32. Morris R (2001) Airborne particulates and hospital admissions for cardiovascular disease: a quantitative review of the evidence. Environ Health Perspect 109(4):495-500

33. Dominici F, Peng R, Bell M, Pham L, McDermott A et al (2006) Fine particulate air pollution and hospital admission for cardiovascular and respiratory diseases. JAMA 295(10):1127-1134

34. Pope C, Muhlestein J, May H, Renlund D, Anderson J et al (2006) Ischemic heart disease events triggered by short-term exposure to fine particulate air pollution. Circulation 114:2443-2448

35. Omori T, Fujimoto G, Yoshimura I, Nitta H, Ono M (2003) Effects of particulate matter on daily mortality in 13 Japanese cities. J Epidemiol 13:314-322

36. Barnett A, Williams G, Schwartz J, Best T, Neller A et al (2006) The effects of air pollution on hospitalizations for cardiovascular disease in elderly people in Australian and New Zealand cities. Environ Health Perspect 114(7):1018-1023

37. Samoli E, Peng R, Ramsay T, Pipikou M, Touloumi G et al (2008) Acute effects of ambient particulate matter on mortality in Europe and North America: results from the APHENA study. Environ Health Perpect 116:1480-1486

38. Silbajoris R, Osornio-Vargas A, Simmons S, Reed W, Bromberg P et al (2011) Ambient particulate matter induces IL-8 expression through an alternative NF- $\mathrm{KB}$ mechanism in human airway epithelial cells. Environ Health Perspect 119:1379-1383

39. Quay J, Reed W, Samet J, Devlin R (1998) Air pollution particles induce IL-6 gene expression in human airway epithelial cells via NF-kappaB activation. Am J Respir Cell Mol Biol 19(1):98-106

40. Driscoll K, Lindenschmidt R, Maurer J, Higgins J, Ridder G (1990) Pulmonary response to silica or titanium dioxide: inflammatory cells, alveolar macrophage-derived cytokines, and histopathology. Am J Respir Cell Mol Biol 2(4):381-390

41. Risom L, Møller P, Loft S (2005) Oxidative stress-induced DNA damage by particulate air pollution. Mutat Res 592(1-2):119-137
42. Riva D, Magalhães C, Lopes A, Lanças T, Mauad T et al (2011) Low dose of fine particulate matter (PM2.5) can induce acute oxidative stress, inflammation and pulmonary impairment in healthy mice. Inhal Toxicol 23(5):257-267

43. Hogg J, Chu F, Utokaparch S, Woods R, Elliott W et al (2004) The nature of small-airway obstruction in chronic obstructive pulmonary disease. NEJM 350(26):2645-2653

44. Diaz-Sanchez D, Taieu A, Casillas A, Dotson A, Saxon A (1996) Enhanced nasal cytokine production in human beings after in vivo challenge with diesel exhaust particles. J Allergy Clin Immunol 98 (1):114-123

45. Diaz-Sanchez D, Tsien A, Fleming J, Saxon A (1997) Combined diesel exhaust particulate and ragweed allergen challenge markedly enhances human in vivo nasal ragweed-specific $\mathrm{IgE}$ and skews cytokine production to a $\mathrm{T}$ helper cell 2-type pattern. J Immunol 158(5):2406-2413

46. Nordenhall C, Pourazar J, Ledin M, Levin J, Sandtrom T et al (2001) Diesel exhaust enhances airway responsiveness in asthmatic subjects. Eur Respir J 17:909-915

47. Behndig A, Mudway I, Brown J, Stenfors N, Helleday R et al (2006) Airway antioxidant and inflammatory responses to diesel exhaust exposure in healthy humans. Eur Resp J 27:359-365

48. Pietropaoli A, Frampton M, Hyde R, Morrow P, Oberdorster G et al (2004) Pulmonary function, diffusing capacity, and inflammation in healthy and asthmatic subjects exposed to ultrafine particles. Inhal Toxicol 16(1):59-72

49. McConnell R, Berhane K, Gilliland F, London S, Vora $\mathrm{H}$ et al (1999) Air pollution and bronchitic symptoms in southern California children with asthma. Environ Health Perspect 107(9):757-760

50. Slaughter J, Lumley T, Sheppard L, Koenig J, Shapiro G et al (2003) Effects of ambient air pollution on symptom severity and medication use in children with asthma. Ann Allergy Asthma Immunol 91(4):346-353

51. O'Connor G, Neas L, Baughn B, Kattan M, Mitchell H et al (2008) Acute respiratory health effects of air pollution on children with asthma in US inner cities. J Aller Clin Immunol 121:1133-1139

52. Desqueyroux H, Pujet J, Prosper M, Squinzai F, Momas I (2002) Short-term effects of low-level air pollution on respiratory health of adults suffering form moderate to severe asthma. Environ Res 89:29-37

53. Rabinovitch N, Strand M, Gelfand E (2006) Particulate levels are associated with early asthma worsening in children with persistent disease. Am J Resp Crit Care Med 173:1098-1105

54. Gent J, Koutrakis P, Belanger B, Triche E, Holford T et al (2009) Symptoms and medication use in children with asthma and trafficrelated sources of fine particle pollution. Environ Health Perspect 117(7):1168-1174

55. Chimonas M, Gessner B (2007) Airborne particle matter from primarily geologic, non-industrial sources at levels below NAAQS is associated with outpatient visits for asthma and quick-relief medication prescriptions among children less than 20 years old enrolled in Medicaid in Anchorage, Alaska. Environ Res 103:387-404

56. Gauderman J, Avol E, Gilliland F, Vora H, Thomas D et al (2004) The effect of air pollution on lung development from 10 to 18 years of age. NEJM 351:1057-1067

57. Avol E, Gauderman J, Tan S, London S, Peters J (2001) Respiratory effects of relocating to areas of differing air pollution levels. Am J Resp Crit Care Med 164:2067-2072

58. Islam T, Gauderman J, Berhane K, McConnell R, Avol E et al (2007) Relationship between air pollution, lung function and asthma in adolescents. Thorax 62:957-963

59. Goss C, Newsom S, Scholdcrout J, Sheppard L, Kaufman J (2004) Effect of ambient air pollution on pulmonary exacerbations and lung function in cystic fibrosis. Am J Resp Crit Care Med 169:816-821

60. Barraza-Villarreal A, Sunyer J, Hernandez-Cadena L, EscamillaNunez M, Sienra-Monge J et al (2008) Air pollution, airway 
inflammation, and lung function in a cohort study of Mexico city schoolchildren. Environ Health Perspect 116:832-838

61. Grigg J (2009) Particulate matter exposure in children. Proc Am Thorac Soc 6:564-569

62. McCreanor J, Cullinan P, Nieuwenhuijssen M, Stewart-Evans J, Malliarou E et al (2007) Respiratory effects of exposure to diesel traffic in persons with asthma. NEJM 357:2348-2358

63. Lee J, Son J, Cho Y (2007) The adverse effects of fine particle air pollution on respiratory function in the elderly. Sci Total Environ 385:28-36

64. Lagorio S, Forastier F, Pistelli R, Iabarone I, Michelozzi P et al (2006) Air pollution and lung function among susceptible adult subjects: a panel study. Environ Health 5:11

65. Downs S, Schindler C, Liu J, Keidel D, Bayer-Oblesby L et al (2007) Reduced exposure to PM10 and attenuated age-related decline in lung function. NEJM 357:2338-2347

66. Gent J, Triche E, Holford T, Belanger K, Bracken M et al (2003) Association of low-level ozone and fine particles with respiratory symptoms in children with asthma. JAMA 290(14):1859-1867

67. Karr C, Lumley T, Achreuder A, Davis R, Larson T et al (2006) Effects of subchronic and chronic exposure to ambient air pollutants on infant bronchiolitis. Am J Epidemiol 165(5):553-560

68. Strickland M, Darrow L, Klein M, Flanders W, Sarnat J et al (2010) Short-term associations between ambient air pollutants and pediatric asthma emergency department visits. Am J Respir Crit Care Med 182:307-316

69. Lin M, Stieb D, Chen Y (2005) Coarse particulate matter and hospitalization for respiratory infections in children younger than 15 years in Toronto: a case crossover analysis. Pediatrics 116: e235-e240

70. Zanobetti A, Franklin M, Koutrakis P, Schwartz J (2009) Fine particulate air pollution and its components in association with cause-specific emergency admissions. Environ Health 8:58

71. Medina-Ramon M, Zanobetti A, Schwartz J (2006) The effect of ozone and PM10 on hospital admissions for pneumonia and chronic obstructive pulmonary disease: a national multicity study. Am J Epidemiol 163(6):579-588

72. Arena V, Mazumdar S, Zborowski J, Talbott E, He S et al (2006) A retrospective investigation of PM10 in ambient air and cardiopulmonary hospital admissions in Allegheny County, Pennsylvania: 1995-2000. J Occup Environ Med 48(1):38-47

73. Peng R, Bell M, Geyh A, McDermott A, Zeger S et al (2009) Emergency admissions for cardiovascular and respiratory diseases and the chemical composition of fine particle air pollution. Environ Health Perspect 117:957-963

74. Bell M, Ebisu K, Peng R, Samet J, Dominici F (2009) Hospital admissions and chemical composition of fine particle air pollution. Am J Respi Crit Care Med 179:1115-1120

75. Colais P, Serinelli M, Faustini A, Stafoggia M, Randi G et al (2009) Air pollution and urgent hospital admissions in nine Italian cities. Results of the EpiAir Project. Epidemiol Prev 33(6 Sup 1):77-94

76. Yi O, Hong Y, Kim H (2010) Seasonal effect of PM10 concentrations on mortality and morbidity in Seoul, Korea: a temperaturematched case-crossover analysis. Environ Res 110:89-95

77. McGowan J, Hider P, Chacko E, Town G (2002) Particulate air pollution and hospital admissions in Christchurch, New Zealand. Aust N Z J Public Health 26:23-29

78. Zeka A, Zanobetti A, Schwartz J (2005) Short term effects of particulate matter on cause specific mortality: effects of lags and modification by city characteristics. Occup Environ Med 62:718-725
79. Zanobetti A, Schwartz J (2009) The effect of fine and coarse particulate air pollution on mortality: a national analysis. Environ Health Perspect 117:898-903

80. Ostro B, Broadwin R, Green S, Feng W, Lipsett M (2006) Fine particulate air pollution and mortality in nine California counties: results from CALFINE. Environ Health Perspect 114:29-33

81. Naess O, Nafstad P, Aamodt G, Claussen B, Rosland P (2007) Relation between concentration of air pollution and cause-specific mortality: four-year exposures to nitrogen dioxide and particulate matter pollutants in 470 neighborhoods in Oslo, Norway. Am J Epidemiol 165(4):435-443

82. Stafoggia M, Faustini A, Rognoni M, Tessari R, Cadum E et al (2009) Air pollution and mortality in ten Italian cities. Epidemil Prev 33(6):65-76

83. Wong C, Vichit-Vadakan N, Kan H, Qian Z (2008) Public health and air pollution in Asia (PAPA): a multicity study of short-term effects of air pollution on mortality. Environ Health Perspect 116:1195-1202

84. Analitis A, Katsouyanni K, Dimakopoulou K, Samoli E, Nikoloulopoulos A (2006) Short-term effects of ambient particles on cardiovascular and respiratory mortality. Epidemiology 17 (2):230-233

85. Conceicao G, Miraglia S, Kishi H, Saldiva P, Singer J (2001) Air pollution and child mortality: a time-series study in Sao Paulo, Brazil. Environ Health Perspect 109(3):347-350

86. Calabrò P, Golia E, Yeh E (2011) Role of C-reactive protein in acute myocardial infarction and stroke: possible therapeutic approaches. Curr Pharm Biotechnol (in press)

87. Wellenius G, Schwartz J, Mittleman M (2005) Air pollution and hospital admissions for ischemic and hemorrhagic stroke among Medicare beneficiaries. Stroke 36(12):2549-2553

88. O'Donnel M, Fang J, Mittleman M, Kapral M, Wellenius G et al (2011) Fine particulate air pollution (PM2.5) and the risk of acute ischemic stroke. Epidemiology 22(3):422-431

89. Villeneuve P, Chen L, Stieb D, Rowe B (2006) Associations between outdoor air pollution and emergency department visits for stroke in Edmonton, Canada. Eur J Epidemiology 21(9):689-700

90. Henrotin J, Besancenot J, Bejot Y, Giroud M (2007) Short-term effects of ozone air pollution on ischaemic stroke occurrence: a case-crossover analysis from a 10-year population-based study in Dijon, France. Occup Environ Med 64(7):439-445

91. Hales S, Blakely T, Woodward A (2010) Air pollution and mortality in New Zealand: cohort study. J Epidemiol Community Health. doi:10.1136/jech.2010.112490

92. Samoli E, Nastos PT, Paliatsos AG, Katsouyanni K, Priftis KN (2011) Acute effects of air pollution on pediatric asthma exacerbation: evidence of association and effect modification. Environ Res 111(3):418-424

93. Peng RD, Chang HH, Bell ML, McDermott A, Zeger SL et al (2008) Coarse particulate matter air pollution and hospital admissions for cardiovascular and respiratory diseases among Medicare patients. JAMA 299(18):2172-2179

94. Ostro B, Roth L, Malig B, Marty M (2009) The effects of fine particle components on respiratory hospital admission in children. Environ Health Perspect 117(3):475-480

95. Anonymous. Indoor air home. United States Environmental Protection Agency, 21 Nov 2011. http://www.epa.gov/iaq/. Accessed on 25 Nov 2011

96. Anonymous. Air quality guide for particle pollution. United States Environmental Protection Agency, August 2003. http://www.epa. gov/airnow/airqualityguideparticles.pdf. Accessed on 25 Nov 2011 